\title{
Reasons why female adults are choosing to undergo Chinamwali- the initiation ceremony for girls in Petauke, Zambia
}

\author{
Jordan Tembo $^{1}$, Patricia Mambwe ${ }^{2}$ \\ ${ }^{1}$ Kalindawalo General Hospital, P.O.Box 560008, Petauke, Zambia \\ ${ }^{2}$ Departments of Nursing, School of Health Sciences, Rusangu University, Monze, Zambia
}

\begin{abstract}
Societies preserve their norms, values, behaviours, customs and beliefs through various cultural ceremonies. Chinamwali the initiation ceremony for girls among the Nsenga cultural grouping in Zambia has been in existence for centuries. Pubertal girls are initiated during chinamwali to prepare them for adulthood and expected social roles they will play. In recent years, chinamwali is rapidly becoming popular among adult females- a stray from the ordained norm. Mothers with children, eagerly enrol to be trained. The objective of this study was to find out reasons prompting adult females to enrol in the cultural school yet their ages are far beyond the adolescent age- band. The study used a cross-sectional study design with a qualitative approach. Using the single-interview per participant, 12 respondents participated in the study. The study found that female adults enrolled for chinamwali training to end stigma and discrimination associated with not being initiated. Some did so out of frustration and anger following scandalization by their exsexual partners that they lacked cultural knowledge and skills to impress a man in bed. Others enrolled in the traditional school as part of marriage preparation. Still some chose to receive instructions and skills necessary to assist them save their crumbling marriages. Chinamwali is receiving remarkable appreciation from the women folk in Petauke- Zambia. Conservative information on gender roles and the wide-ranging in-depth sexuality lessons and demonstrations among others are catching the ear of adult females. Motivated to experience social change in their lives, these new mature cultural students willingly, at a huge sacrifice, pause by laying aside all parental responsibilities temporarily, by going back to their roots to be coached traditional principles.
\end{abstract}

Keywords: society, initiation, ceremony, puberty, culture

\section{INTRODUCTION}

$\mathrm{T}$ he goal of each society is to reproduce itself for continuity. Culture acts as an eternal social glue holding together in a stable and orderly disposition, stratified groups and individual units. Culture, 'the language, beliefs, values, norms, behaviours, and even material objects that are passed from one generation to the next' (Henslin 1995: 35) forms the social package that society transmits to all its new comers. 'Acquisition of the various competences and pieces of information that society acquits' (Morin 2018:1) its members occurs incrementally or spontaneously 'from interactions with others in the social context' (Nabavi 2012: 3).
At first, cultural transmission is paced and flows naturally. In some cultures in Africa, the process gets amplified, emphatic and intensified at puberty. In these societies, puberty is the defining phase of life. It is the 'rite of transition' (Munthali 2007: 2) to adulthood but also the transition into the sexual world (Van Gennep, 1960). It is a valued rite of passage for it is key to passing down teachings and traditions on adulthood, gender, relationships and sexuality to young people (United Nations Population Fund, 2017:5). It is common in many African cultures to conduct ceremonies marking the transition to adulthood during adolescence. World Health Organization (WHO, 2006) defines adolescents as individuals in the 10-19 year age group. These ceremonies are mandatory. Scholars observe that initiation ceremonies for girls in various cultures are celebrated between 8-20 years (Brown 1963).

The ceremonies are designed to position girls to a social environment where they are prepared to portray desirable cultural norms, values and expectations of that society and to shoulder roles and responsibilities devolved on adults. In various cultural communities in Zambia, initiation ceremonies for girls are conducted during adolescence. The Bemba and Chewa cultural groups conduct their rites of passages for girls at puberty (Mutale, 2017). So do the Nsenga cultural group of Sinda and Petauke districts in Eastern Province of Zambia. In recent years however, it is becoming radically different among the Nsenga cultural group. In this cultural group, mothers with children beyond adolescence age-band are undergoing initiation ceremony together with young girls. They leave their children behind with family members and choose to suspend their daily life activities for two to four weeks of total exclusion. They choose to be treated as novices yet already adults with a wealth of experience.

What is the source of this awakening interest for initiation among female adults when they were altogether past the age limit culturally required? Between October 2020 and February, 2021, one Nsenga community of Petauke district with an approximate population of 1,200 initiated 6 adult women with an age range of 28 and 38years. Petauke district is situated approximately 430 kilometres from Zambia's capital city- Lusaka. The rural town is situated along the main road that connects Zambia and Malawi. The district has a 
population of 256,000 people as at 2020 . It is inhabited by the Nsenga cultural group.

Most international truck drivers love to stop over for a night at Petauke. Some say they enjoy the company of Nsenga women. The objective of this study was to explore reasons why mothers with helpless toddlers at grand cost chose to be initiated into the pubertal initiation ceremony for girlsChinamwali.

\section{MATERIALS AND METHODS}

Cultural issues related to initiations and marriages are sensitive for the involved to share them with any person openly. Doing so meant insulting tradition and stripping oneself of the respect and dignity. Therefore, participants for this study did not use the women who had undergone initiation rather the study used elderly women counselors and elderly men. These were chosen because they were the custodians of traditions in their community. The study was conducted between October 2020 to February 2021. To ensure participants were safe from COVID-19, the study avoided meeting- like situations such as holding Focus Group Discussions so that they do not become super- spreaderpoints of the virus in the community. As such, the study used the single-interview-per-participant data collection method. Qualitative research experts provide various advice on the number of participants for selection for an interview study. Saunders (2012) advises 4-12 study units for a homogeneous population. This study used 12 participants. For the alternative perspective, the study used men for 'men's decisions and behaviours assist to perpetuate rigid social and cultural expectations' (MenEngage 2014: 7) affecting women and girls. Consent was first obtained from the three head men heading three separate participants' villages. Participants' anonymity and confidentiality were assured as their names were not recorded anywhere neither were participants allowed to introduce themselves using their names. After explaining the purpose of the study, verbal consent was obtained after which demographic data for the participants was obtained. Each interview lasted 50minutes. Refreshments were provided at the end of the interview for hydration only. After data collection, recorded interviews were listened to several times. This was done to ensure interviewees' perspectives were familiar for the researcher to draw out themes.

\section{RESULTS}

Question: What do you know about the initiation ceremony for girls in your culture?

The question was meant to elicit responses that defined initiation ceremony and proceeded to explain important parameters associated with it. Respondents defined Chinamwali- as a traditional requirement for every girl who had reached puberty to shed childhood and put on adulthood. Some defined Chinamwali as a special point in a girl's life when she was assisted to clearly understand who she really was as a woman and what was expected of her by society beginning with her immediate family. Males defined Chinamwali as a traditional obligation for a girl to learn how to satisfy a man's sexual desires while adopting strict hygiene rituals and maintaining a loyal respectful role as a woman towards men and the elderly. Respondents explained that during initiation ceremony a girl was secluded from society. She was attached to the main woman-counsellor called asungi.

The role of asungi was to teach, guide, protect and take full responsibility of the girl's welfare until she learnt all of the expected norms, values, and behaviours meant to fit her into society as an adult.

\section{Definition of initiation ceremony}

Men and women gave polar opposite versions of the definition of initiation ceremony. Emphasis from women was on teaching a girl the culturally expected way of life including behaviours, dress, respect towards elders, attitude, gender roles and mores. On the other hand, men's emphasis in their definition of initiation ceremony for girls was on teaching a girl how to handle herself during menses, how to dispose soiled pads, how to please a man in bed through participatory sexual dances and how to keep his genitals clean and shaved.

Chinamwali ni mwambo wamakolo wa bana a cisikana akango kutha msinkhu. Uyu mwambo umilila pa kuphunzisa mwana wa cisikana kupyolela mwa asungi bake cikhalidwe coyenela monga mofunikila kubvwalila, kucitila ngati pali awisi, mofunikira kuyankhila amai bake nabanthu akulu akulu ndiponso osati kukonda masobela ojoba joba pali banthu a agwe no onesha malisece bake,

Initiation ceremony is our cultural way of life
conducted the moment a girl has her first menses. The
ceremony is designed to instruct a girl-child through
her woman instructor society's expectations in terms
of modest dress, how to sit and behave when in the
presence of her father, the way she is expected to
answer her mother and other elderly people and not
to engage in play behaviours that will make her jump
all over else she falls and exposes her nakedness
(Female respondent).

Chinamwali nimwambo wa asikana pala akangoti watha msinku basi omuika mung'anda akuti amulangize mozisungila pala ngati alikumwezi. Ndiponso omulangiza mosungila mwanalume mucikwati kumubvinillila no mumute kuti ankhale kilini,

\begin{abstract}
Initiation ceremony is our cultural practice for girls after their first menses. It involves secluding a girl for lessons and instructions on hygiene rituals when she is attending her menses and how to satisfy her man sexually and to shave his pubic hair (Male respondent).
\end{abstract}

When participants were asked to state the age range for those eligible to undergo initiation ceremony their answers were 
similar. All of them emphatically said at puberty but gave an age range between 12 to 16years. They made it clear that a girl aged 18 to 20 years was still admitted into the cultural school. Two female respondents pointed out that they had observed growth variation among girls in which at 9 years, a girl developed breasts for fear that she can be impregnated while tender she was enrolled in the cultural school early.

Question: Explain to me why female adults enrol in the cultural school of initiation ceremony for girls when they are way beyond the age-band of puberty?

Responses were categorized into 4 themes namely: rough treatment from fellow women, leaked scandalizing story from Ex- sexual partner, part of marriage preparation and wanting to save her marriage.

Similar responses and expressions from both women and men were noted but men explained more clearly on social stigma an uninitiated woman suffers at the hands of fellow women.

\section{Rough treatment from fellow women}

Respondents explained that the traditional standard in the village was that every girl by the time she became a fully grown woman she would have had undergone initiation ceremony. Any woman whether educated or not, if identified as lacking cultural knowledge on matters related to what was taught during initiation ceremony for girls she was at first looked at with suscipicion. Confirmation was made through protracted questioning and when it was clear that the woman did not possess the most treasured cultural knowledge she was ridiculed and called derogatory names such as buthu meaning damsel- one who knows nothing. From then on, she was forced to go underground in all women-related social events. She was denied participation in honour- associated traditional privileges of being asungi. She was denied entry into where Chinamwali was conducted for fear of desecrating it. She was barred from attending women's cultural refresher courses called vigubu because she was regarded a social infant. She was not chosen to be part of the delegates to help assist settle marital problems because she was regarded as a 'woman baby' lacking knowledge and experience to help others. If she dared attend the events, the callous treatment from the women folk dipped farther into open hostility against her.

Stalked by social stigma and surrounded by discriminatory attitude from her fellow women the excluded woman, though advanced in age was forced to leave her children in foster care for initiation ceremony as a mature entrant.

Ngati mzimai aliye lobe mung'ánda azibiletu naye kuti nkhondo ikulu yati akumane nayo na azimai ayake. Omupatula ati ndaba ni buthu lusaziba ciliconse koma ni munthu wabana bake ndola. Kunkhala kumujeda, kumu lesha kupezekako ku cinamwali. Akacita nthota kulutako aweleko na nsoni cifukwa amunyoze ngati kamwana ka tontho,

A woman who has not undergone initiation ceremony should be prepared to face an ugly battle against her own women folk. She is excluded from important women-related social events because she was considered a damsel though a mother with children who had attained puberty. They backbite her and bar her from attending chinamwali. If she insists going they shamed her and treated her like a child until she was forced to get initiated as well (Male respondent).

Mzimai aliye lobe mung'anda sakwanisha kunkhala nayeke bwino cifukwa akaziba tyala nishi zabvuta. Ankhale ponenewa, pojedewa, potiliwa matika m'paka naye alobe mung'anda nazungo yati zii, ulemu wonse apasiwe osati ndakuti niwo phunzila izo zutheka lini,

A woman who is not initiated into adulthood by means of the cultural ceremony has difficulties relating to her fellow women especially when they know she is blank. She is ridiculed and mudded until she was forced to get initiated to win her social respect and dignity of a woman (Woman respondent).

\section{Leaked humiliating story from Ex- sexual partner}

Over leaked scandalizing story from Ex-sexual partner, respondents explained that uninitiated women who had sexual encounters with men who were cultural oriented were at risk of being scandalized. Men leaked the humiliating story of a woman lacking cultural knowledge and skills in bed. She was derided, scorned and laughed at in the community. The woman became emotionally desolate in such a hostile humiliating social environment. She had two options, get up and leave or stay but get initiated. Most women preferred the latter option.

Mwanalume walala na mwanakazi aliye lobe mung'anda omusula no falisa mbili yo mupepusha ula mwanakazi. So cunkhalapo nikuloba mung'anda, a man who has slept with a woman has not undergone initiation despises her and circulates damaging and humiliating story about so the woman has no option but to be initiated (Male respondent).

\section{Part of marriage preparation}

Respondents reported that women who had children out of wedlock, one after another before they could be initiated envied to settle down in a marriage relationship later in life. Through interaction with other women and through experience they found that the pressing reality among the men folk was for the woman to display cultural knowledge and skills in bed. In order to make themselves marketable, they chose to be initiated in adulthood and wait for a man who could marry them.

Msikana wathamangila kuphula bvumo thapu thapu koma aliye alume kusogolo pofuna kuti akwatiliwe basi kwake nikuloba mung'anda kuti analume akambvwa kuti aloba mung'a atengeke kuti oziba mwambo, 
a girl who falls pregnant several time before she undergoes initiation later in life envies to get married and settle in life so she has to be initiated in order to market herself out to men, (Female respondent).

\section{Wanting to save crumbling marriage}

Participants reported that undergoing initiation for a married woman was a life line for her marriage. A woman facing menace of divorce because the husband was altogether unhappy because the wife could not perform her expected cultural duties was prompted by the prevailing hostility at home to get initiated so that she could pour water on her husband's stoked flames. Respondents explained that the moment the woman received the lessons and began to practice what she was taught, the entire whirlwind threatening to rip through her marriage faded away quickly.

Kufuna kupulumusa cikwati, mphela mwanakazi oloba mung'anda. Akaphunzila noyamba kubvicita basi na kamvulumvulu wasila mung'anda,

In the quest to save her marriage, the woman was forced to get initiated so she could save her marriage. The moment she graduated and began to practice the whirlwind dies down, (Female respondent).

\section{DISCUSSION}

Undergoing initiation ceremony as a girl is a cultural obligation in some African societies. Among Zambian cultural groupings, initiation ceremony for girls is conducted at puberty. When older women aged 30 to 45 years, mothers with children, retreat their steps from adulthood and condense themselves by getting initiated as adults is a social phenomenon worth of social inquiry. This study set out to explore reasons why adult females stooped to undergo initiation meant for pubertal girls. This study found that women who did not get initiated faced social challenges in their adulthood. In the village, they became a centre of gossip, ridicule and social exclusion from women-related gatherings whose objective was to instruct girls, conduct cultural refresher courses or settle marriage disputes in the community. Respondents reported that in all these events, an uninitiated woman was barred because she was considered buthu as one of the respondent remarked, a woman who is not initiated no matter her age is a buthu. She does not know anything so she should not be allowed ku chinamwali or $k u$ vigubu (Female participant). These findings are supported by the study findings by Alister Munthali, Maryse Kok and Tasneem Kakal (2018) in which the scholars found that women who were not initiated could not mix freely with those who were schooled in the cultural school. The women were regarded as children regardless of age (Munthali et al., 2018).

This study found that women who were not initiated became victims of men's masculine patriarchal attitude. Their Exsexual partners derided them and circulated a damning report of the observed cultural deficiencies in bed hence subjecting them to utter humiliation, emotional and psychological violence. In an attempt to fight back shame and humiliation they got forced to go for initiation. Over patriarchal masculinities, the United Nations asset that in many societies, it was common for men to entertain ideas and practices of masculinity that emphasized superiority of masculinity over femininity and the authority of men over women. This exposed women to all forms of violence including emotional and psychological violence (UN Women, 2016). The study also found that older single women, whose age was past the adolescent age, chose to be initiated as part of marriage preparation. Respondents explained that since men loved a woman with a history of chinamwali initiation, a woman who chose to be initiated even in adulthood to solidify her chances for marriage as she had been trained and obtained vital information and skills required in marriage.

The findings tally with those from a study conducted in Tanzania in which girls about pubertal age underwent initiation to receive knowledge and skills that would prepare them for marriage (Anu, 2017). This study also found that some married women chose to undergo chinamwali training as a measure to save their dwindling marriage. The woman sought elderly women to bring conservatism values, norms and behaviours to save her marriage, as one of the female respondent said;

\begin{abstract}
a marriage where a man is dissatisfied because his woman fails to perform accordingly, the woman seeks the assistance of elderly women to teach her old tested ways to save her marriage (Female respondent).
\end{abstract}

\section{CONCLUSION}

Chinamwali is receiving remarkable appreciation from the women folk in Petauke- Zambia. Conservative information on gender roles and the wide-ranging in-depth sexuality lessons and demonstrations among others are catching the ear of adult females. Motivated to experience social change in their lives, these new mature cultural students willingly, at a huge sacrifice, pause by laying aside all parental responsibilities temporarily, go back to their roots to be coached traditional principles.

\section{RECOMMENDATION}

The study recommends that more young females to be recruited as asungi so that continuity of traditional customs is assured. The study further recommends full documentation of chinamwali for safe storage in the libraries as traditions are under serious threat of disappearing due to the impact of westernization.

\section{AUTHORS' CONTRIBUTIONS}

JT was responsible for the study conception and design, data collection, and analysis. PM edited the manuscript. 


\section{ACKNOWLEDGEMENTS}

The authors are grateful to the three village head men for their permission and for the participants for their time and contributions to the study.

Table1.Demographic characteristics of participants

\begin{tabular}{|c|c|c|}
\hline Variables & Male Respondents & Female Respondents \\
\hline $\begin{array}{c}\text { Number of } \\
\text { participants }\end{array}$ & 5 & 7 \\
\hline Age( in Years) & $602(16.6 \%)$ & $653(25 \%)$ \\
$643(25 \%)$ & $674(33.3 \%)$ \\
\hline Marital status & Married 5(41.6\%) & $\begin{array}{c}\text { Married 5(41.6\%) } \\
\text { Widowed 2(16.6\%) }\end{array}$ \\
\hline Occupation & $\begin{array}{c}\text { Subsistence farmer } \\
5(41.6 \%)\end{array}$ & $\begin{array}{c}\text { Subsistence farmer } \\
7(58.3 \%)\end{array}$ \\
\hline
\end{tabular}

\section{REFERENCES}

[1] Anu, N. (2017). Traditional unyango training in Tanzania- a step to adolescence or a leap to motherhood. Bachelor's Thesis. Laurea University of Applied Sciences

[2] Brown, J. (1963). A cross-cultural study of female initiation rites. American Anthropologist, 65(4): 837-853

[3] Henslin, J.M.(1995). Sociology. A Down-to-Earth Approach (2 ${ }^{\text {nd }}$ ed.). Massachusetts: Simon \& Schuster Company

[4] Morin, O.(2018). Cultural Transmission. DOI: 10.10.100219781118924396.wbiea1882

www.researchgate.net/publication
[5] Nabavi, R.T.(2012).Bandura's Social Learning Theory \& Social Cognitive Learning Theory www.researchgate.net/publication

[6] Munthali, A.C., Zulu, E.M. (2007). The Timing and role of initiation Rites in preparing Young People for Adolescence and Responsible Sexual and Reproductive Behaviour in Malawi. African Journal of Reproductive Health vol 11(3) December, 2007

[7] Munthali, A.C., Kok, M.K., Kakal, T. (2018). YES I DO. Initiation ceremonies in Traditional Authority Liwonde in Machinga District in Southern Malawi: What do they influence young people's behaviour regarding sex and relationships? Study report initiation ceremonies YID Final www.Kit.nl

[8] MenEngage Alliance (2014). Men, Masculinities, and Changing Power: A Discussion Paper on Engaging Men in Gender Equality From Beijing 1995 to 2015 www.unfpa.org resource-pdf

[9] Saunders, M.N.K. (2012). 'Choosing research participants' in G. Symon and C.Cassell (eds.). Qualitative Organizational Research: Core Methods and Current Challenges, pp35-52 London: Sage

[10] United Nations Population Fund (2017). A Guidance Note on alternative Rites of Passage and Cultural Practices for Adolescents and Young People in East and Southern Africa- A UNFPA Esaro Programme Guidance Note www.unfpa

[11] UN Women (2016). Self-Learning Booklet: Understanding Masculinities and violence Against Women and Girls. Trainingcentre.unwomen.org

[12] Van Gennep, A.(1960). The Rites of Passage. London: Routledge and Kegan Paul

[13] World Health Organization (2006). Orientation Programme on Adolescent Health for Health care Providers Handout New Modules

http://www.who.int/rpc/research_ethics/hivtestingpolicy_en_pdf.p df. 2 